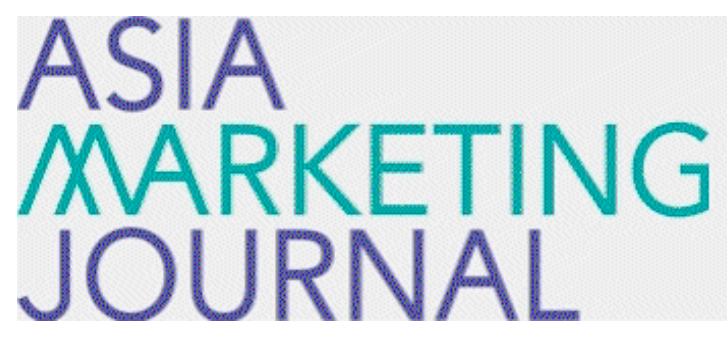

ASIA MARKETING JOURNAL

Volume 15 | Issue 3

Article 1

$10-30-2013$

\title{
Consumer Associative Network Analysis on Device and Service Convergance
}

Sang Man Han

Jang Hyuk Lee

Sun Young Park

Jo

Follow this and additional works at: https://amj.kma.re.kr/journal

Part of the Marketing Commons

\section{Recommended Citation}

Han, Sang Man; Lee, Jang Hyuk; Park, Sun Young; and Jo (2013) "Consumer Associative Network Analysis on Device and Service Convergance," Asia Marketing Journal: Vol. 15 : Iss. 3 , Article 1.

Available at: https://doi.org/10.53728/2765-6500.1555

This Article is brought to you for free and open access by Asia Marketing Journal. It has been accepted for inclusion in Asia Marketing Journal by an authorized editor of Asia Marketing Journal. 


\title{
Consumer Associative Network Analysis on Device and Service Convergence*
}

\author{
Sangman Han** \\ Janghyuk Lee*** \\ Sun-Young Park* \\ Woonghyeon $\mathrm{Jo}^{* * * * *}$
}

Our research brings managerial insights for developing new digital convergence of devices and services. To explain the phenomenon of device and service convergence, we combine two different approaches from separate research fields: a perceptual mapping technique generally used for segmentation in marketing and associative network analysis mobilized to understanding network structure of core and peripheral as well as the information mediating role of nodes in network science. By combining these two approaches, we provide an in-depth analysis of the associations among devices and services by assessing the centrality of device and service nodes in an associative network. This is done by examining the connections between these services and devices as well as investigating the role of mediation in the combined device-service associative network. Our results based on bi-partite network analysis of survey responses from 250 Internet Protocol (IP) television viewers show which device and which service will play the major role in future device and service convergence as well as which characteristics and functionalities have to be incorporated into future convergence. Among the devices, the mobile handset with the betweenness centrality of 0.26 appears to be the device that would lead future device convergence. Among the services, wireless broadband with the betweenness centrality of 0.276 appears to be the service on which future service convergence needs to be developed. This result is quite unexpected, since wireless broadband has a lower penetration rate than other services, such as fixed broadband and cable TV. In addition, we indicate the possibility of converging devices, such as personal digital assistant (PDA) and mobile handset, and services, such as IPTV and mobile Internet, into wireless broadband services in the future.

Key words: Associative network, betweenness centrality, digital convergence

\footnotetext{
* The authors thank the National Research Foundation of Korea for research grant (NRF-2010-330-B00110) funded by the Korean government. Janghyuk Lee thanks Korea University Business School for its generous research grant.

** Professor of Marketing. Sungkyunkwan University Graduate School of Business(smhan@skku.edu)

*** Associate Professor of Marketing. Korea University Business School(janglee@korea.ac.kr), Corresponding author

**** Associate Professor of High-tech Marketing, Konkuk University, William F. Miller School of MOT(sypark@konkuk.ac.kr)

***** C1 Pro, Cheil Worldwide(hansawi21@naver.com)
} 


\section{Introduction}

The demand for a variety of digital content has been increasing as consumers enjoy more free time and a more enhanced purchase power than before. Forrester Research forecasts that the volume of American online paid content. such as digital music, filmed entertainment, video games, information, and services, has increased from 6.6 billion United States dollars (US \$) in 2008 to US \$ 10.8 billion in 2013 , with an annual growth rate of $10.3 \%$ (Epps and Best 2008). The vitalization of the digital content market is closely linked to that of the increase in services and devices using digital content. The rapid increase in the use of digital content can be considered as the first stage of digital convergence, and included the fields of computing, publishing, and broadcasting (Yoffie 1997). Recently, the tide of digital convergence combined devices, networks, and media, which created hybrid services across industries (Farber and Baran 1977). In the field of information technology, Xu et al. (2010) addressed the role of mobile video for 3G mobile Internet by applying a model of media convergence acceptance and Raj et al. (2010) proposed a model for fixed and mobile convergence. Joo et al. (2008) addressed the effect of perceived similarity and usage behavior on adoption intention of convergence product.
However, the diffusion of new services generated by digital convergence depends substantially on their perceived value by the consumer. Therefore, it is necessary to examine how the consumer perceives the value provided by a digital convergence service and how this value varies depending on which $\mathrm{de}^{-}$ vices and services are combined. In this study we analyze possible combinations of digital services and devices by using an associative network analysis technique. The results will indicate the position of each service and device in an associative network, from which the best combination of services and devices for successful diffusion can be inferred.

\section{Theoretical Background}

According to Farber and Baran (1977) the first instance of the concept of digital convergence was the phenomenon where the three industries of computing, publishing, and broadcasting converged to create new business opportunities. In this phenomenon, consumer, company, and government interact with one other to ensure functional integration, convergence extension, value creation based on digitalization, enhanced networks, and new technology convergence. It is expected that digital convergence will develop from intra industry convergence to inter industry con- 
vergence and ultimately evolve to create an ubiquitous environment that enables networking among devices, objects, facilities, and humans, through the functional integration of digitalized devices, contents, and networks (Cho, Lee and Cheon 2007). The common requirement emphasized by various researchers for the future of convergence, is the functional integration of devices (Yoffie 1997: Henten, Samarajiva and Melody 2003: Stiglitz 2003). The reason for this is that all services require more or less the same minimum hardware criteria for effective service delivery.

To ascertain the most effective combination of device and service, we make use of the associative network analysis proposed by Anderson (1983). The associative network shows how each node of memory with fragments of information is linked to one another (Blackwell, Miniard and Engel 2006). In the associative network, the node is considered as a unit of memory and the link is considered as an association between memory units. This method is applied in perceptual mapping to indicate consumer perceptions of a certain object. A metaphor elicitation technique (Zaltman Metaphor Elicitation Technique, ZMET) was developed by Zaltman to analyze the association among constructs as perceived by the consumer, whether they are recognized at a conscious, or at an unconscious level (Zaltman and Robin 1995). In reaction to ZMET, John et al. (2006) proposed a more standardized individual inter- view approach to perceptual mapping, namely the Brand Concept Maps (BCM). This technique makes use of individual, unstructured, in-depth interview results that indicate the association among constructs as nodes, linked directly and indirectly to a specific brand. These results are acquired by aggregating individual perceptual maps. In BCM, the strength between two constructs (nodes) is measured by the frequency of responses given by respondents.

However, both approaches are limited to show the association among many focal objects, such as devices and services, as they have one focal object (i.e., a brand) in the center from which linked constructs are developed. In this study, we apply a bipartite network approach for analyzing the association among nodes (devices and services) that measure the link between two types of nodes indirectly (Zhou et al. 2007). In Table 1, as both brand $\mathrm{B}$ and brand $\mathrm{C}$ have attribute $\mathrm{W}$, a link between brand $B$ and brand $C$ is created. Brands $A B, A D$, and $B D$ are linked through their common attribute $\mathrm{X}$, and brand $\mathrm{CD}$ through their common attribute $Z$. In the same manner, attributes XY, WX, WZ, and XZ are linked through common brands. Based on the listed links, an associative network can be described.

Another reason for using the bipartite network approach is that it provides various numeric indicators that describe the characteristics of a network. Henderson et al. (1998) explain that the parity, complementarity, and 
〈Table 1〉 Bipartite Network Projection Example

\begin{tabular}{|c|c|c|c|c|}
\hline & Brand A & Brand B & Brand C & Brand D \\
\hline Attribute W & 0 & 1 & 1 & 0 \\
\hline Attribute X & 1 & 1 & 0 & 1 \\
\hline Attribute $\mathrm{Y}$ & 1 & 0 & 0 & 0 \\
\hline Attribute Z & 0 & 0 & 1 & 1 \\
\hline
\end{tabular}

cannibalization between attributes can be explained by network indicators such as centrality, cohesion, position, density, and structural equivalence. In our research, we focus on betweenness centrality ${ }^{1)}$ of a node, varying between 0 and 1 , which is equal to the number of shortest paths from all nodes to all others that pass through that node. Suppose a node $j$ has to go through node $i$ to communicate with node $k$. The more often node $i$ is located on the shortest path between numerous node dyads, the higher node $i$ 's potential to control network interactions (Freeman 1979).

Once the notion of betweenness centrality is applied to an associative network of devices and services based on the consumer's perception, we can assess the connecting capability of each service and device. The higher the betweenness centrality of a node (device or service), the greater its chance to play a major role in digital convergence.

\section{Methodology}

\subsection{Data}

We use a part of survey data collected for a research project commissioned by the Electronics and Telecommunication Research Institute (ETRI) in September 2008. A question regarding the perceived association between a device and a service (0: not associated, 1: associated) was raised for 156 combinations between 12 services (wired broadband Internet, wireless broadband Internet, mobile Internet, satellite digital multimedia broadcasting [s-DMB], terrestrial digital multimedia broadcasting [t-DBM], cable television [CATV], fixed phone, cellular phone, voice over Internet protocol [VoIP], internet protocol television [IPTV], telematics, and home network) and 13 digital devices (desktop computer, laptop computer, mobile personal

1) Betweenness centrality is measured as $C_{b}\left(N_{j}\right)=\sum_{j=i} \frac{g_{\mu}\left(N_{j}\right)}{g_{j}}$ where $g_{j k}$ is the number of geodesic paths between node $j$ and $k$. and $g_{j k}\left(N_{i}\right)$ is the number of geodesics between $j$ and $k$ that contain node $i$. Its measure in 2-mode network is explained in Borgatti and Everett (1997). 
computer [mobile $\mathrm{PC}$ ], highdefinition television [HDTV], portable media player [PMP], personal digital assistant [PDA], mobile handset, digital video recorder [DVR], digital camcorder, digital camera, MPEG audio layer III [MP3] player, game console, and car navigation device).

Professional surveyors visited 250 randomly selected households watching IPTV in South Korea to ask questions regarding the services and devices mentioned above. Among the respondents, 59.2\% (148 respondents) were male. The age range of all respondents was between $20 \mathrm{~s}$ and $50 \mathrm{~s}$ with the proportion of $27 \%, 54 \%, 14 \%$ and $5 \%$ for each age bracket of 10 . As this research was conducted in the early stages of adopting the IPTV service, the proportion of young male respondents was relatively high $(13.6 \%$ of the male respondents were in their 20 s and $32.4 \%$ of the male respondents were in their 30s).

\subsection{Extraction of a Bipartite Network}

\subsubsection{Filtering Rule Set-up and Application}

As mentioned earlier in Table 1, we can construct a bipartite network with two different node types (device and service) for each individual network. However, it is difficult to draw appropriate conclusions from 250 separate bipartite networks. Therefore, we aggregate the individual responses to form an overall associative bipartite network. Table 2 shows the frequency of answers from 250 respondents if they associated a device with a particular service. The average association frequency is 45.5 and the standard deviation is 35.9 .

If all the nodes are linked to one other in a network, one cannot extract useful information from that network. Henderson et al. (1998) applied the $4 / 9$ rule by selecting cells that contain four or more answers out of nine (Henderson et al. 1998). In our research, we apply a filtering rule to select the cell whose frequency is larger than the average +1 standard deviation. In this case, the threshold is $81.4(45.5+35.9)$, which is lower than that of Henderson et al's cells (it should be 250* $4 / 9=111.1$ ). Based on this filtering rule, in Table 2 we set the value of cells to 1 only if their frequency is higher than 81.4. Otherwise, they are set to zero.

\subsubsection{Network Extraction by Projection}

The filtered association between device and service can be transformed into two networks by a projection process. If we consider Table 3 as a matrix, $A$, a device network $(13 \times 13)$ in Table 4 can be projected by multiplying $A$ by its transposed matrix, $\operatorname{tr}(A)$. Additionally, a service network $(12 \times 12)$ is projected by $\operatorname{tr}(A) A$. As the cells on the diagonal line are not informative, because of self connection, and the projected network matrix is symm- 
〈Table 2〉 Perceived Association between Device and Service

\begin{tabular}{|c|c|c|c|c|c|c|c|c|c|c|c|c|}
\hline & $\begin{array}{c}\text { Fixed } \\
\text { Broadband } \\
\end{array}$ & \begin{tabular}{|c|} 
Wireless \\
Broadband \\
\end{tabular} & $\begin{array}{l}\text { Mobile } \\
\text { Internet }\end{array}$ & $\begin{array}{c}\text { S- } \\
\text { DMB }\end{array}$ & $\begin{array}{c}\text { T- } \\
\text { DMB }\end{array}$ & CATV & $\begin{array}{l}\text { Fixed } \\
\text { Phone }\end{array}$ & $\begin{array}{l}\text { Cellular } \\
\text { Phone }\end{array}$ & VoIP & IPTV & Telematics & $\begin{array}{c}\text { Home } \\
\text { Network }\end{array}$ \\
\hline Desktop & 177 & 71 & 14 & 15 & 27 & 42 & 14 & 13 & 89 & 52 & 25 & 82 \\
\hline Laptop & 36 & 194 & 50 & 41 & 48 & 15 & 13 & 36 & 67 & 33 & 41 & 58 \\
\hline Mobile PC & 19 & 142 & 109 & 78 & 80 & 11 & 5 & 44 & 48 & 22 & 41 & 40 \\
\hline HDTV & 47 & 23 & 13 & 54 & 49 & 128 & 15 & 17 & 13 & 132 & 24 & 73 \\
\hline PMP & 20 & 81 & 82 & 93 & 123 & 22 & 7 & 27 & 34 & 26 & 41 & 32 \\
\hline PDA & 14 & 108 & 120 & 82 & 91 & 17 & 9 & 53 & 51 & 21 & 36 & 30 \\
\hline $\begin{array}{l}\text { Mobile } \\
\text { Handset }\end{array}$ & 9 & 94 & 25 & 10 & 39 & 43 & 12 & 10 & 89 & 136 & 93 & 130 \\
\hline DVR & 43 & 40 & 19 & 42 & 45 & 71 & 13 & 13 & 21 & 63 & 32 & 44 \\
\hline $\begin{array}{c}\text { Digital } \\
\text { Camcorder }\end{array}$ & 25 & 47 & 26 & 33 & 61 & 26 & 4 & 13 & 17 & 32 & 39 & 66 \\
\hline $\begin{array}{l}\text { Digital } \\
\text { Camera }\end{array}$ & 25 & 63 & 27 & 32 & 50 & 23 & 8 & 18 & 19 & 29 & 32 & 77 \\
\hline MP3 & 31 & 69 & 43 & 42 & 68 & 16 & 6 & 31 & 15 & 14 & 31 & 42 \\
\hline $\begin{array}{l}\text { Game } \\
\text { Console }\end{array}$ & 58 & 94 & 57 & 34 & 39 & 20 & 11 & 14 & 16 & 36 & 21 & 42 \\
\hline Navigation & 15 & 100 & 57 & 115 & 131 & 22 & 6 & 26 & 26 & 19 & 74 & 35 \\
\hline
\end{tabular}

〈Table 3〉 Filtered Perceived Association between Device and Service

\begin{tabular}{|c|c|c|c|c|c|c|c|c|c|c|c|c|}
\hline & $\begin{array}{c}\text { Fixed } \\
\text { Broadband }\end{array}$ & $\begin{array}{c}\text { Wireless } \\
\text { Broadband }\end{array}$ & $\begin{array}{c}\text { Mobile } \\
\text { Internet }\end{array}$ & $\begin{array}{c}\text { S- } \\
\text { DMB }\end{array}$ & $\begin{array}{c}\text { T- } \\
\text { DMB }\end{array}$ & CATV & $\begin{array}{c}\text { Fixed } \\
\text { Phone }\end{array}$ & $\begin{array}{c}\text { Cellular } \\
\text { Phone }\end{array}$ & VoIP & IPTV & Telematics & $\begin{array}{c}\text { Home } \\
\text { Network }\end{array}$ \\
\hline Desktop & 1 & 0 & 0 & 0 & 0 & 0 & 0 & 0 & 1 & 0 & 0 & 1 \\
\hline Laptop & 0 & 1 & 0 & 0 & 0 & 0 & 0 & 0 & 0 & 0 & 0 & 0 \\
\hline Mobile PC & 0 & 1 & 1 & 0 & 0 & 0 & 0 & 0 & 0 & 0 & 0 & 0 \\
\hline HDTV & 0 & 0 & 0 & 0 & 0 & 1 & 0 & 0 & 0 & 1 & 0 & 0 \\
\hline PMP & 0 & 0 & 1 & 1 & 1 & 0 & 0 & 0 & 0 & 0 & 0 & 0 \\
\hline PDA & 0 & 1 & 1 & 1 & 1 & 0 & 0 & 0 & 0 & 0 & 0 & 0 \\
\hline $\begin{array}{c}\text { Mobile } \\
\text { Handset }\end{array}$ & 0 & 1 & 0 & 0 & 0 & 0 & 0 & 0 & 1 & 1 & 1 & 1 \\
\hline DVR & 0 & 0 & 0 & 0 & 0 & 0 & 0 & 0 & 0 & 0 & 0 & 0 \\
\hline $\begin{array}{c}\text { Digital } \\
\text { Camcorder }\end{array}$ & 0 & 0 & 0 & 0 & 0 & 0 & 0 & 0 & 0 & 0 & 0 & 0 \\
\hline $\begin{array}{c}\text { Digital } \\
\text { Camera }\end{array}$ & 0 & 0 & 0 & 0 & 0 & 0 & 0 & 0 & 0 & 0 & 0 & 0 \\
\hline MP3 & 0 & 0 & 0 & 0 & 0 & 0 & 0 & 0 & 0 & 0 & 0 & 0 \\
\hline $\begin{array}{c}\text { Game } \\
\text { Console }\end{array}$ & 0 & 1 & 0 & 0 & 0 & 0 & 0 & 0 & 0 & 0 & 0 & 0 \\
\hline Navigation & 0 & 1 & 0 & 1 & 1 & 0 & 0 & 0 & 0 & 0 & 0 & 0 \\
\hline
\end{tabular}


$\langle$ Table 4〉 Device Network

\begin{tabular}{|c|c|c|c|c|c|c|c|c|c|c|c|c|c|}
\hline & Desktop & Laptop & $\begin{array}{c}\text { Mobile } \\
\text { PC }\end{array}$ & HDTV & PMP & PDA & $\begin{array}{c}\text { Mobile } \\
\text { Handset }\end{array}$ & DVR & $\begin{array}{c}\text { Digital } \\
\text { Camcorder }\end{array}$ & $\begin{array}{c}\text { Digital } \\
\text { Camera }\end{array}$ & MP3 & $\begin{array}{c}\text { Game } \\
\text { Console }\end{array}$ & Navigation \\
\hline Desktop & & & & & & & & & & & & & \\
\hline Laptop & 0 & & & & & & & & & & & & \\
\hline Mobile PC & 0 & 1 & & & & & & & & & & & \\
\hline HDTV & 0 & 0 & 0 & & & & & & & & & & \\
\hline PMP & 0 & 0 & 1 & 0 & & & & & & & & & \\
\hline PDA & 0 & 1 & 2 & 0 & 3 & & & & & & & & \\
\hline $\begin{array}{c}\text { Mobile } \\
\text { Handset }\end{array}$ & 2 & 1 & 1 & 1 & 0 & 1 & & & & & & & \\
\hline DVR & 0 & 0 & 0 & 0 & 0 & 0 & 0 & & & & & & \\
\hline $\begin{array}{c}\text { Digital } \\
\text { Camcorder }\end{array}$ & 0 & 0 & 0 & 0 & 0 & 0 & 0 & 0 & & & & & \\
\hline $\begin{array}{c}\text { Digital } \\
\text { Camera }\end{array}$ & 0 & 0 & 0 & 0 & 0 & 0 & 0 & 0 & 0 & & & & \\
\hline MP3 & 0 & 0 & 0 & 0 & 0 & 0 & 0 & 0 & 0 & 0 & & & \\
\hline $\begin{array}{c}\text { Game } \\
\text { Console }\end{array}$ & 0 & 1 & 1 & 0 & 0 & 1 & 1 & 0 & 0 & 0 & 0 & & \\
\hline Navigation & 0 & 1 & 1 & 0 & 2 & 3 & 1 & 0 & 0 & 0 & 0 & 1 & \\
\hline
\end{tabular}

〈Table 5〉 Service Network

\begin{tabular}{|c|c|c|c|c|c|c|c|c|c|c|c|c|}
\hline & $\begin{array}{c}\text { Fixed } \\
\text { Broadband }\end{array}$ & $\begin{array}{c}\text { Wireless } \\
\text { Broadband }\end{array}$ & $\begin{array}{l}\text { Mobile } \\
\text { Internet }\end{array}$ & $\begin{array}{c}\mathrm{S}^{-} \\
\mathrm{DMB}\end{array}$ & $\begin{array}{c}\text { T- } \\
\text { DMB }\end{array}$ & CATV & $\begin{array}{l}\text { Fixed } \\
\text { Phone }\end{array}$ & $\begin{array}{l}\text { Cellular } \\
\text { Phone }\end{array}$ & VoIP & IPTV & Telematics & $\begin{array}{l}\text { Home } \\
\text { Network }\end{array}$ \\
\hline \multicolumn{13}{|l|}{$\begin{array}{c}\text { Fixed } \\
\text { Broadband }\end{array}$} \\
\hline $\begin{array}{c}\text { Wireless } \\
\text { Broadband }\end{array}$ & 0 & & & & & & & & & & & \\
\hline $\begin{array}{l}\text { Mobile } \\
\text { Internet }\end{array}$ & 0 & 2 & & & & & & & & & & \\
\hline S-DMB & 0 & 2 & 2 & & & & & & & & & \\
\hline T-DMB & 0 & 2 & 2 & 3 & & & & & & & & \\
\hline CATV & 0 & 0 & 0 & 0 & 0 & & & & & & & \\
\hline $\begin{array}{l}\text { Fixed } \\
\text { Phone }\end{array}$ & 0 & 0 & 0 & 0 & 0 & 0 & & & & & & \\
\hline $\begin{array}{l}\text { Cellular } \\
\text { Phone }\end{array}$ & 0 & 0 & 0 & 0 & 0 & 0 & 0 & & & & & \\
\hline VoIP & 1 & 1 & 0 & 0 & 0 & 0 & 0 & 0 & & & & \\
\hline IPTV & 0 & 1 & 0 & 0 & 0 & 1 & 0 & 0 & 1 & & & \\
\hline Telematics & 0 & 1 & 0 & 0 & 0 & 0 & 0 & 0 & 1 & 1 & & \\
\hline $\begin{array}{c}\text { Home } \\
\text { Network }\end{array}$ & 1 & 1 & 0 & 0 & 0 & 0 & 0 & 0 & 2 & 1 & 1 & \\
\hline
\end{tabular}


etric, we use only the data under the diagonal line for network analysis. Each cell represents the strength of the link between two devices (or services).

\section{Results}

\subsection{Device Network}

Figure 1 illustrates the associative network between devices perceived by the consumer watching IPTV. Mobile devices, such as the mobile handset, laptop, mobile PC, PDA, navigation device, and game console, are 10cated in the center of the device network and densely connected to one other. As these devices are closely and densely connected, the chance for creating a converged device among them would be higher than among other devices. In contrast, fixed devices, such as the HDTV and desktop computer, are located on the periphery of the device network, implying that there are limited opportunities to create new converged devices that have the same characteristics as these devices. When looking one level down, the mobile PC is located in the center around the PDA. PMP, and navigation device, and the mobile handset is centered around all devices, except the PMP.

To identify which device has the highest potential to lead the convergence, we have to ascertain the betweenness centrality of each device that explains the extent to which one device can be mediated to another. If the betweenness centrality of a device is high, this

〈Figure 1〉 Device Network

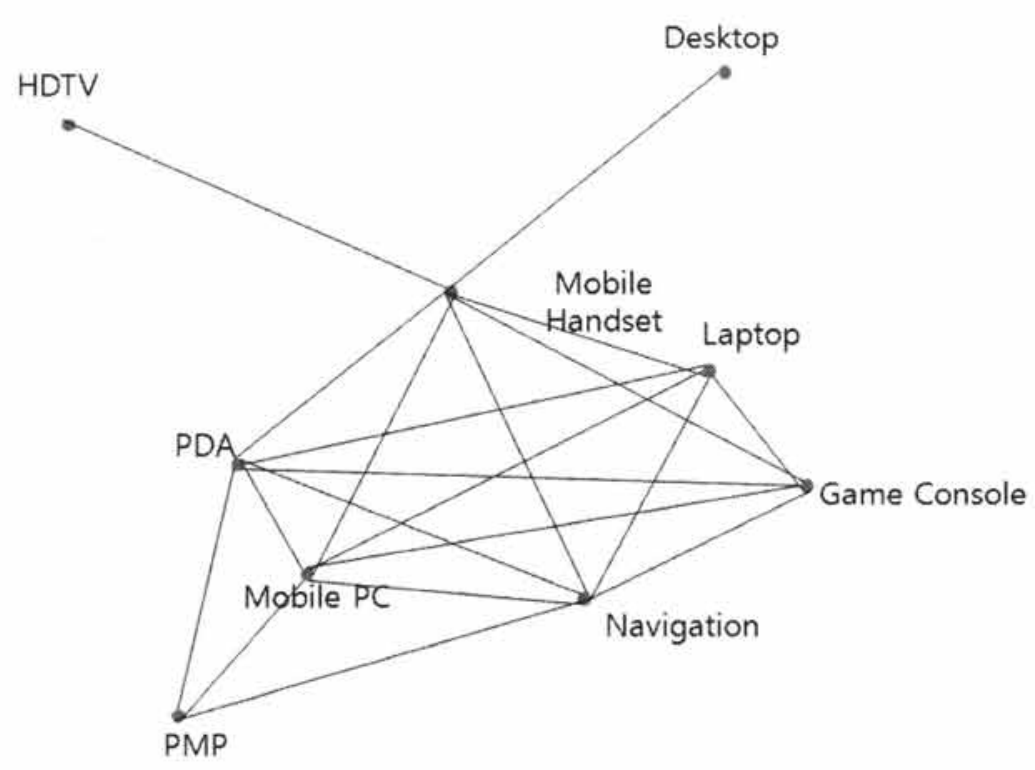


device tends to lie on the shortest path of other device dyads. As a result, it is more likely for this device to lead the convergence than other connected devices. From Table 4 , we compute the betweenness centrality of each device using Pajek 1.27.

As one can observe from the associative network graph, the mobile handset has the highest betweenness centrality of 0.464 . That means around $46 \%$ of the shortest paths of device dyads are mediated by the mobile handset. It is therefore very likely that the mobile handset will play the key role in $\mathrm{de}^{-}$ vice convergence. Its contenders are the mobile PC, PDA, and navigation device, each with a betweenness centrality of 0.060 , which is substantially smaller than that of the mobile handset. The rest of the devices record a betweenness centrality of zero, which means that there is hardly a possibility that they will lead device convergence.

\subsection{Service Network}

Figure 2 illustrates the associative network among services perceived by the consumer watching IPTV. First, it can be observed that fixed and mobile services tend to be separated from the rest of the services and form their own cluster. Fixed services are located on the left-hand side and mobile services on the right-hand side of the graph. This means that in case of convergence we can expect that there will be two different streams of service convergence: fixed and mobile at the first round. Wireless broadband services can be centered around the convergence of mobile services, Among fixed services, IPTV and VoIP are relatively close to the center. However, services such as cable television (CATV) and fixed broadband, which have high current penetration rates, are located on the periphery of the network, which implies their

〈Figure 2〉 Service Network

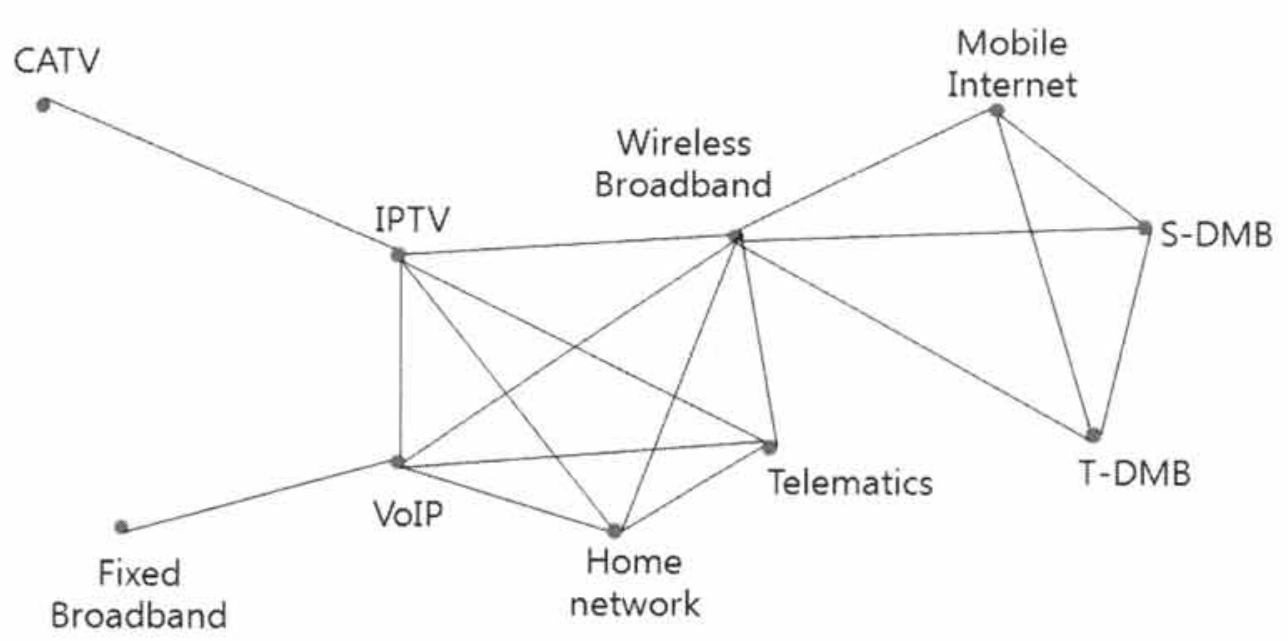


limited role in future service convergence.

The above findings are confirmed by betweenness centrality measures. Wireless broadband services are listed at the top of the graph, with a betweenness centrality of 0.500 , followed by IPTV and VoIP. each with a betweenness centrality of 0.222 . The rest of the services record a betweenness centrality of zero. It is therefore likely for wireless broadband to lead service convergence, followed by IPTV and VoIP.

\subsection{Combined Service-Device Network}

To obtain a complete picture of digital convergence among devices and services, we aggregate device and service networks to generate a combined network. In the network analyses of devices and services we pointed out the prominent role of the mobile handset for device convergence and of wireless broadband for service convergence. It has also been confirmed that mobile handsets and wireless broadband services are located in the center of combined networks, whereas fixed devices and services tend to be located on the lefthand side and mobile services on the righthand side of the network. Compared to fixed devices and services, mobile ones appear to be densely linked to one to another. This means that the consumer may accept mobile deviceservice convergence much easier than fixed deviceservice convergence.
For example, DMB services and mobile Internet are linked and they may therefore be converged. When they are linked to a PDA, the PDA will play the key role in convergence, as the device that delivers this new converged service. If a converged service, such as interactive $\mathrm{DMB}$ combining the functionality of mobile Internet and DMB is delivered through a PDA device, the consumer may easily perceive their value with close association among these services and device.

This approach can be applied to indirectly linked services as well. In the combined associative network, IPTV and mobile Internet services are not linked directly and do not have any device in common. If a marketer wants two services to be converged, he/she can maneuver devices such as a mobile handset and a PDA on the shortest path between two services. As for the device, the converged device of a mobile handset and a PDA is smart phone. If a new converged service is developed on the platform of wireless broadband by adding the functionality of IPTV, and this new service is available on a smart phone, its adoption rate will be much higher than any other converged service matched with another device.

The betweenness centrality measure listed in Table 6 confirms the mediating role of devices and services such as wireless broadband, mobile handsets, IPTV, VoIP, and home networks for new digital convergence of devices 
〈Figure 3〉 Combined Service-Device Network

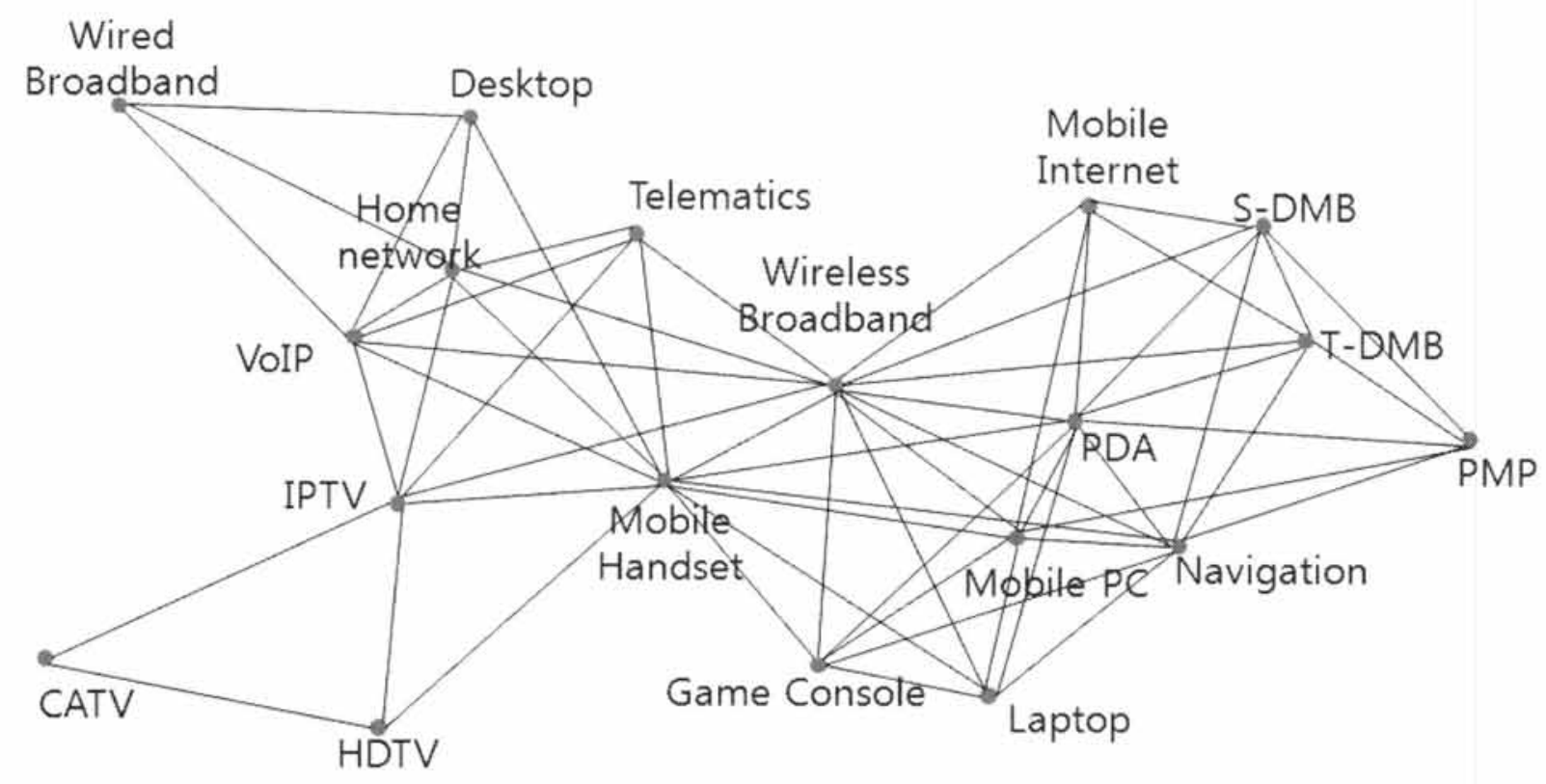

$\langle$ Table 6〉 Betweenness Centrality of Service and Device

\begin{tabular}{|c|c|}
\hline Device and Service & Betweenness Centrality \\
\hline Wireless Broadband & 0.276 \\
\hline Mobile Handset & 0.260 \\
\hline IPTV & 0.108 \\
\hline VoIP, Home network & 0.056 \\
\hline PDA & 0.053 \\
\hline Navigation & 0.043 \\
\hline Mobile PC & 0.032 \\
\hline HDTV & 0.017 \\
\hline Desktop & 0.011 \\
\hline Mobile Internet & 0.008 \\
\hline S-DMB, T-DMB & 0.006 \\
\hline PMP & 0.004 \\
\hline Telematics, Laptop, Game Console, CATV, Wired Broadband & 0.000 \\
\hline
\end{tabular}

and services.

These results show the gap between the current penetration rate of services and their role in future convergence. Most highly ranked services, such as wireless broadband (i.e., Wibro service), IPTV, VoIP, and home networks, suffer from relatively low penetration rates because of various reasons. However, the con- 
sumer perceives their role to be important for future digital convergence. To cope with consumer expectations, a marketing manager needs to develop new services that incorporate the characteristics of closely linked services and choose appropriate devices, or develop new converged ones, for fostering new converged services. As for the devices, it is expected that the mobile handset will lead future convergence. Therefore, the functionality of linked devices will be loaded into mobile handsets to play the main role in future device convergence.

\section{Discussion}

The main contribution of this research is providing managerial insights into driving digital device and service convergence. In order to do this, we combined two different approaches developed in previous research from two respective fields. Until now, the perceptual mapping technique has mainly been used in consumer psychology and marketing research to visualize the consumer's perception of a certain object and the associative network analysis has mainly been used in the area of social network analysis and graph theory. By combining these two approaches, we provided an in-depth analysis of association among devices and services by examining the connections among them as well as the role of mediation in the combined device-service associative network.

Our results show which device and service play the main role in future device and service convergence as well as which characteristics and functionalities have to be incorporated in future convergence. Among the devices, the mobile handset appears to be the device that will lead future device convergence and among the services, wireless broadband appears to be the main service on which future service convergence need to be developed. This result is quite unexpected, since this service has a lower penetration rate than other services, such as fixed broadband and cable TV. In addition, we indicated the possible combination of devices such as the PDA and the mobile handset to converge IPTV and mobile Internet into a wireless broadband service in the future.

Despite its contribution, our research has the following limitations that can be improved upon in future studies. Firstly, the level of our analysis only focused on the services and devices as a whole. This research can be elaborated by conducting an in-depth study of these services and devices on an attribute level especially considering its number of attributes and diversity. Thereby, more insightful findings can be rendered. Secondly, we did not reach the network analysis results by applying various filtering rules. Our choice of the threshold of average plus one standard 
deviation in accordance with the 4/9 rule of Henderson et al. (1998) would be arbitrary. Therefore, in future threshold based research, various filtering rules need to be used to perform a sensitivity test of network analysis results. Finally, we only analyzed survey answers on questions about the perceived association between devices and services among users of IPTV services (relatively early adopters of digital services) of specific age group. Therefore, our analysis is limited to the descriptive level of specific users. In order to validate the findings of associative network analysis, they need to be matched either with choice response, or with real choice behavior in reaction to device and service convergence taking into consideration of user heterogeneity in terns of demographics as well as device and service usage experience.

〈Received May 9. 2013〉

〈Revised July 18. 2013〉

〈Accepted July 23. 2013〉

\section{References}

Anderson, John R. (1983), The Architecture of Cognition, Harvard University Press: Cambridge, MA.

Blackwell, Roger D., Paul W. Miniard and James F. Engel (2006), Consumer Behavior, 10th ed., Thomson South-Western:
Mason.

Borgatti, Stephen P. and Martin G. Everett (1997), "Network Analysis of 2-mode Data," Social Networks, 19, 243-269.

Cho, D., H. Lee and H. Cheon (2007), "A study on Mobile Convergence Product Using Multi Regression Analysis Methods," Emotional Science, 10(1), (March), 13-21.

Epps, Sarah R. and Mark Best (2008), “US B2C Online Paid Content: Five-Year Forecast," Forrester Research. Available at: http://www.forrester.com/rb/Research/ us_b2c_online_paid_content_five-year_ forecast/q/id/47558/t/2 (accessed 15 July 2009)

Farber, D. and P. Baran (1977), "The Convergence of Computing and Telecommunications Systems," Science, 195(4283), 116670.

Freeman, Linton C. (1979), "Centrality in social networks: Conceptual clarification," Social Networks, 1, 215-39.

Henten, Anders, Rohan Samarajiva and Willaim H. Melody (2003), "Designing Next Generation Telecom Regulation: ICT Convergence or Multi sector Utility?" Report on the WDR Dialogue Theme.

Henderson, Geraldine R., Dawn Iacobucci and Bobby J. Calder (1998), "Brand diagnostics: Mapping branding effects using consumer associative networks," European Journal of Operational Research, 111. 306-27. 
John, Deborah R., Barbara Loken, Kyeongheui Kim and Alokparna B. Monga (2006), "Brand Concept Maps: A Methodology for Identifying Brand Association Networks," Journal of Marketing Research, XLIII, (November), 549-63.

Joo, Young-Hyuck, Yong-Cheol Kim and Jong-Kun Jun (2008), "The Effect of Perceived Similarity and Usage Behavior of Component Products on Adoption Intentions of Convergence Product - Focused on Wibro in Telecommunication Market, Asia Marketing Journal, 9(4), 79-115.

Raj, Mayank, Avinash Narayan, Sajib Datta and Sajal K. Das and Jogen K. Pathak (2010), "Fixed Mobile Convergence: Challenges and Solutions," IEEE Communications Magazine, December, 26-34.

Stiglitz, Nils (2002), “Industry Dynamics and Types of Convergence: the Evolution of the Personal Digital Assistant Market in the 1990s and Beyond," Proceedings of DRUID Summer Conference in Copenhagen, 6-8 June 2002, 1-41.

$\mathrm{Xu}$, Xin, Will Wai Kit Ma and Eric Wing Kuen See-To (2010), “Will Mobile Video Become the Killer Application for 3G Mobile Internet? a model of media convergence acceptance," Information Systems Frontiers, 12, 311-322.

Yoffie, David B. (1997), Digital Convergence, Harvard Business School Press: Boston, MA.

Zaltman, Gerald and Robin H. Coulter (1995), "Seeing the Voice of the Customer: MetaphorBased Advertising Research," Journal of Advertising Research, 35 (July - August), 35-51.

Zhou, Tao, Jie Ren, M. Matus Medo and Yie-Cheng Zhang (2007), "Bipartite network projection and personal recommendation," Physical Review E 76, 046115. 